\title{
FAKTOR-FAKTOR YANG BERHUBUNGAN DENGAN KEJADIAN ANEMIA PADA IBU HAMIL
}

\author{
Tessa Sjahriani ${ }^{11}$, Vera Faridah'2) \\ 1ProdiPendidikan Dokter, Fakultas Kedokteran, Universitas Malahayati \\ Email: tessasah@gmail.com \\ 2ProdiPendidikan Dokter, Fakultas Kedokteran, Universitas Malahayati \\ Email: verafaridah@malahayati.ac.id
}

\begin{abstract}
Background: The prevalence of anemia in pregnant women in Indonesia ranges from 20-80\%, but in general a lot of studies show greater $50 \%$. In the western part of Indonesia it is high, Aceh is $56.6 \%$, North Sumatra is $77.9 \%$, West Sumatra is $8.9 \%$, Riau is $65.6 \%$, Jambi is $74.2 \%$, South Sumatra is $58.3 \%$, Lampung 60 , $7 \%$.

Purpose: To analyze the factors associated with the incidence of anemia in pregnant women in the working area of Lahat Bandar Jaya Lahat Health Center in 2016.

Methods: Sampling using analytical design, cross sectional design with purposive sampling technique, the sample amounted to 49 respondents. The independent variables are the age of pregnant women, parity, birth distance, gestational age, and knowledge. And the dependent variable is the incidence of anemia in pregnant women. Data were analyzed using Chi Square.

Results: The highest age of pregnant women was $<20$ years old and $>35$ years old as many as 28 respondents $(75.1 \%)$, $<4$ parity as many as 45 respondents (81.63\%), $<2$ years birth spans were 26 respondents (53, 1\%), TM III as many as 25 respondents (51.0\%), less knowledge as many as 28 respondents (57.1\%), the incidence of anemia was 26 respondents (53.1\%). There was a relationship between the age of pregnant women $(p=0,000)$, birth distance $(p=0,000)$, gestational age $(p=0,000)$, and knowledge $(p=0,000)$, with the incidence of anemia in pregnant women. And there is no parity relationship $(p=0.472)$ with anemia in pregnant women.

Conclusion: There is a relationship between the age of pregnant women, birth distance, gestational age, and knowledge, with the incidence of anemia in pregnant women. And there is no relationship between parity and the incidence of anemia in pregnant women
\end{abstract}

Keyword : anemia in pregnant women, birth distance, parity, gestational age

\section{ABSTRAK}

Latar belakang :Prevalensi anemia pada wanita hamil di Indonesia berkisar $20-80 \%$, tetapi pada umumnya banyak penelitian yang menunjukkan lebih besar yaitu $50 \%$. Di wilayah Indonesia bagian barat tergolong tinggi, Aceh 56,6\%, Sumatera utara $77,9 \%$, Sumatera Barat 8,9\%, Riau 65,6\%, Jambi $74,2 \%$, Sumatera Selatan $58,3 \%$, Lampung $60,7 \%$.

Tujuan penelitian : Untuk menganalisis faktor-faktor yang berhubungan dengan kejadian anemia pada ibu hamil di wilayah kerja Puskesmas Bandar Jaya Lahat Kabupaten Lahat tahun 2016.

Metode: Pengambilan sampel menggunakan desain analitik, rancangan cross sectional dengan teknik purposive sampling, Sampel berjumlah 49responden. Dengan variabel independen adalah usia ibu hamil, paritas, jarak kelahiran, usia kehamilan, dan pengetahuan. Dan variabel dependen adalah kejadian anemia pada ibu hamil. Data dianalisis menggunakan Chi Square.

Hasil penelitian: Usia ibu hamil terbanyak yaitu usia $<20$ tahun dan $>35$ tahun sebanyak 28 responden $(75,1 \%)$, paritas $<4$ sebanyak 45 responden $(81,63 \%)$, jarak kelahiran $<2$ tahun sebanyak 26 responden $(53,1 \%)$, TM III sebanyak 25 responden (51,0\%), pengetahuan kurang sebanyak 28 responden $(57,1 \%)$, kejadian anemia sebanyak 26 responden $(53,1 \%)$. Ada hubungan antara usia ibu hamil $(p=0,000)$, jarak kelahiran $(p=0,000)$, usia kehamilan $(p=0,000)$, dan pengetahuan $(p=0,000)$, dengan kejadian anemia pada ibu hamil. Dan tidak ada hubungan paritas $(p=0,472)$ dengan anemia pada ibu hamil. 
Simpulan : Ada hubungan antara usia ibu hamil, jarak kelahiran, usia kehamilan, dan pengetahuan, dengan kejadian anemia pada ibu hamil. Dan tidak ada hubungan paritas dengan kejadian anemia pada ibu hamil.

Kata kunci : Anemia ibu hamil, Jarak Kelahiran, Paritas, Usia kehamilan.

\section{PENDAHULUAN}

Anemia adalah suatu kondisi atau keadaan ditandai dengan penurunan kadar hemoglobin $(\mathrm{Hb})$, hematokrit atau jumlah sel darah merah. Kadar $\mathrm{Hb}$ dan sel darah sangat bervariasi tergantung pada usia, jenis kelamin, ketinggian suatu tempat, serta keadaan fisiologi tertentu (Sudoyo, 2013). Menurut Depkes (2009) anemia dalam kehamilan adalah kondisi ibu dengan kadar hemoglobin dibawah 11 gr\% pada trimester I dan III atau $<10,5$ gr\% pada trimester II. Anemia lebih sering dijumpai dalam kehamilan karena dalam kehamilan kebutuhan akan zat-zat makanan bertambah dan terjadi perubahanperubahan dalam darah dan sumsum tulang (Prawirohardho, 2014). Anemia pada umumnya terjadi di seluruh dunia, terutama di negara berkembang, pada kelompok sosial ekonomi rendah, meliputi pendidikan, pekerjaan, pendapatan. Pada kelompok dewasa terjadi pada wanita usia reproduksi, terutama wanita hamil dan wanita menyusui karena banyak mengalami defisiensi Fe.

Menurut World Health Organization prevalensi ibu hamil yang mengalami anemia defisiensi $\mathrm{Fe}$ sekitar $35-75 \%$ yang semakin meningkat seiring dengan pertambahan usia kehamilan. Sementara persentase wanita hamil dari keluarga miskin terus meningkat seiring bertambahnya usia kehamilan dalam trimester I (sebanyak 8\%), trimester II sebanyak 12\%, dan trimester III sebanyak 29\% (Fatmah, 2014).

Secara keseluruhan, anemia terjadi pada $45 \%$ wanita di negara berkembang dan $13 \%$ di negara maju (Fatmah, 2014). Sedangkan menurut Kementrian Kesehatan Republik Indonesia (2013) $8 \%$ pada negara maju, 40,1\% di negara Indonesia.

Prevalensi anemia pada wanita hamil di Indonesia berkisar $20-80 \%$, tetapi pada umumnya banyak penelitian yang menunjukkan anemia pada wanita hamil yang lebih besar dari $50 \%$. Di wilayah Indonesia bagian barat daerah tergolong tinggi, anemia di Aceh sebanyak 56,6\%, Sumatera utara $77,9 \%$, Sumatera Barat 8,9\%, Riau 65,6\%, Jambi $74,2 \%$, Sumatera Selatan $58,3 \%$, Lampung $60,7 \%$. Dalam penanggulangan anemia pada ibu hamil, Depkes telah mempunyai kebijaksanaan agar anemia tidak berdampak terhadap kondisi persalinan dan nifas yang beresiko terhadap kematian (Handoko, 2010). Prevalensi anemia yang tinggi dapat membawa akibat negatif seperti gangguan dan hambatan pada pertumbuhan dan kekurangan $\mathrm{Hb}$ dalam darah mengakibatkan kurangnya oksigen yang ditransfer ke seluruh tubuh maupun otak (Manuaba, 2010).

Dari penelitian Herawati, dkk (2010). Faktorfaktor yang Berhubungan dengan Anemia Gizi pada Ibu Hamil di Puskesmas Jalaksana Kuningan Tahun 2010. Jurnal Kesehatan Kartika, 1(1), pp.51-8. diketahui bahwa dari 81 responden yang diteliti, sebagian besar responden (54,3\%) menderita anemia dengan kadar haemoglobin $<11$ gr\% (Herawati, dkk, 2010). Berdasarkan Survey Demografi dan Kesehatan Indonesia/SDKI (2012), Angka Kematian Ibu (AKI) tercatat mencapai 359 per 100 ribu kelahiran hidup. Ratarata kematian ini jauh melonjak dibandingkan hasil SDKI tahun 2007 yang mencapai 228 per 100 ribu, meningkatnya kematian ibu tentu sangat mempersulit pemerintahan yang sebelumnya bertekad menurunkan AKI hingga 108 per 100 ribu pada 2015 sesuai dengan target Millenium Development Goals/MDGs (Kemenkes, 2012).

Anemia pada ibu hamil masih merupakan salah satu masalah nasional karena mencerminkan nilai kesejahteraan sosial ekonomi masyarakat, dan pengaruhnya sangat besar terhadap kualitas sumber daya manusia. Anemia kehamilan disebut 'potential danger to mother and child', karena itulah anemia memerlukan perhatian dari semua pihak yang terkait dalam pelayanan kesehatan pada lini terdepan (Manuaba, 2010).

Tahun 1970 Depkes RI telah melaksanakan suatu program pemberian tablet besi pada ibu hamil di Puskesmas dan posyandu dengan mendistribusikan tablet tambah darah, dimana satu tablet berisi $200 \mathrm{mg}$ ferrosulfat dan $0,25 \mathrm{mg}$ asam folat (setara dengan $60 \mathrm{mg}$ besi dan $0,25 \mathrm{mg}$ asam folat). Setiap ibu hamil dianjurkan minum tablet besi dengan dosis satu tablet setiap hari selama kehamilannya dan empat puluh hari setelah melahirkan. Tablet besi disediakan oleh pemerintah dan diberikan kepada ibu hamil secara gratis melalui sarana pelayanan kesehatan (Depkes RI, 2009).

Kebutuhan zat besi pada setiap kehamilan \pm $900 \mathrm{mg} \mathrm{Fe}$ untuk pembentukan sel darah ibü, 
plasenta dan darah janin. Jika persediaan cadangan Fe minimal, maka setiap kehamilan akan menguras persendiaan Fe tubuh dan menimbulkan anemia pada kehamilan berikutnya. Pada kehamilan relatif terjadi anemia karena darah ibu hamil mengalami hemodilusi dengan peningkatan volume $30-40 \%$ yang puncaknya terjadi pada usia kehamilan 32-34 minggu. Jumlah peningkatan sel darah $18-30 \%$, Hb sekitar $19 \%$.

Bila $\mathrm{Hb}$ ibu sebelum hamil sekitar $11 \%$, dengan terjadinya hemodilusi akan mengakibatkan anemia hamil fisiologis, dan $\mathrm{Hb}$ ibu beresiko menurun menjadi 9,5-10\%. Setelah persalinan dengan lahirnya plasenta dan perdarahan ibu akan beresiko mengalami kehilangan zat esi sekitar 900 mg. Saat laktasi, ibu masih memerlukan kesehatan jasmani yang optimal untuk dapat menyiapkan ASI untuk perkembangan da pertumbuhan bayi. Dalam keadaan anemia, laktasi tidak mungkin dapat dilaksanakan dengan baik (Manuaba, 2010).

Hasil survey SDKI (2012) persentase dari keseluruhan wanita hamil, sekitar $40 \%$ telah mendapatkan informasi tentang tanda-tanda komplikasi kehamilan, dari keseluruhan wanita hamil sebesar $60 \%$ telah mendapatkan pelayanan berupa pemberian pil zat besi atau sirup (Kemenkes, 2012). Berdasarkan data dari Dinas Kesehatan Propinsi Sumatera Selatan tahun 2009 jumlah ibu hamil sebanyak 634 orang, dengan anemia sebanyak 232 orang $(36,5 \%)$, sedangkan pada tahun 2010 jumlah ibu hamil sebanyak 670 orang, dengan anemia sebanyak 491 orang $(73,2 \%)$ (Dinkes Propinsi Sumatera Selatan, 2010),

Salah satu faktor penyebab anemia pada ibu hamil adalah kurangnya pengetahuan tentang pentingnya mengkonsumsi makanan bergizi yang dapat memenuhi kebutuhan ibu dan bayinya selama kehamilan. Zat gizi yang sangat penting bagi ibu hamil adalah zat besi, jika asupan ibu kurang akan meningkatkan resiko terjadinya anemia, yang berakibat pada gangguan pertumbuhan dan perkembangan janin. Dampak anemia pada ibu hamil yaitu abortus, partus premature, partus lama, perdarahan postpartum, syok, infeksi intrapartum/postpartum (Prawirohardjo, 2014).

Upaya pencegahan dan penanggulangan anemia pada ibu hamil menurut Depkes (2012) yaitu : Meningkatkan konsumsi zat besi dan sumber alami, terutama makanan sumber hewani (hemiron) yang mudah diserao seperti hati, daging, ikan. Selain itu perlu ditingkatkan juga makanan yang banyak mengandung vitamin $\mathrm{C}$ dan $\mathrm{A}$ (buah dan sayuran) untuk membantu penyerapan zat besi dan membantu proses pembentukan $\mathrm{Hb}$.Fortifikasi bahan makanan yaitu menambahkan zat besi, asam folat, vitamin $A$ dan asam amino esensial pada bahan makanan yang dimakan secara luas oleh kelompok sasaran. Penambahan zat besi ini umumnya dilakukan pada bahan makanan hasil produksi industri pangan.Suplementasi besi-folat secara rutin selama jangka waktu tertentu, bertujuan untuk meningkatkan kadar $\mathrm{Hb}$ secara cepat. Dengan demikian suplemen zat besi hanya merupakan salah satu upaya pencegahan dan penanggulangan kurang zat besi yang perlu diikuti dengan cara lain.

Untuk itu pengetahuan ibu hamil tentang zat besi sangat diperlukan untuk mencegah ibu mengalami anemia (Esse P, 2012). Penelitian Esse P (2012) menunjukkan bahwa sebagian besar ibu hamil mempunyai pengetahuan kurang tentang penyebab, gejala, dan dampak anemia serta zat pelancar dan penghambat absorpsi zat besi yaitu sebanyak 33 orang $(65 \%)$.

Penelitian Herawati, dkk (2010) menyebutkan bahwa ibu hamil di Puskesmas Jalaksana Kuningan sebagian besar umur kehamilan berusia 4-6 bulan (Trisemester II) $(44,4 \%)$, sebagian besar merupakan multigravida $(50,6 \%)$, dan berdasarkan paritas sebagian besar responden $(64,2 \%)$ ibu hamil tidak beresiko (paritas $\leq 3$ kali). Sedangkan penelitian Noverstiti, E., (2012) menyebutkan bahwa sebagian besar responden memiliki paritas yang rendah $(77,05 \%)$, jarak kehamilan yang jauh $(67,21 \%)$ dan tingkat pengetahuan yang baik. Berdasarkan survey pendahuluan yang dilakukan di wilayah kerja Puskesmas Bandar Jaya Lahat, Kabupaten Lahat pada bulan April 2016, dari 84 orang ibu hamil yang memeriksakan diri ke Puskesmas Bandar Jaya 225 orang diantaranya mengalami anemia dengan $\mathrm{Hb}$ $<11 \mathrm{gr} \%$ dan dari beberapa ibu hamil yang berumur $<20$ tahun yang diwawancarai menyampaikan bahwa dalam perolehan tablet zat besi yang diberikan, tidak dikonsumsi secara baik dengan alasan ketidaktahuan manfaat tablet zat besi.

\section{METODOLOGIPENELITIAN}

Penelitian ini merupakan jenis penelitian kuantitatif analitik dengan rancangan penelitian cross sectional. Rancangan ini dipilih untuk menilai faktor-faktor yang berhubungan dengan kejadian anemia pada ibu hamil. Analisis menyangkut ada tidaknya hubungan antara variabel, dan pengambilan data dilakukan pada suatu waktu tertentu dengan cara wawancara kepada responden dengan memakai kuesioner. Penelitian dilakukan di wilayah kerja Puskesmas tahun 2016 pada bulan Desember 2016.Pengumpulan data diperoleh dari 
data sekunder di Puskesmas Bandar Jaya Lahat Kabupaten Lahat tahun 2016.

Populasi dalam penelitian ini adalah ibu hamil di wilayah kerja Puskesmas Bandar Jaya Lahat Kabupaten Lahat tahun 2016, sebanyak 49 responden. Besar sampel dihitung dengan menggunakan rumus Slovin. Adapun penentuan sampel dilakukan dengan teknik purposive sampling, yaitu penentuan sampel yang dilakukan secara acak. Maka didapatkan sampel pada penelitian ini adalah 49 responden dengan kriteria sampel sebagai berikut :

- Kriteria inklusi :

1) Ibu hamil yang memeriksakan kehamilan di Puskesmas Bandar Jaya Lahat Kabupaten Lahat tahun 2016.

2) Ibu hamil yang bersedia menjadi responden.

- Kriteria eksklusi :

Tidak memiliki penyakit kronis seperti kanker, ulkus peptikum, diabetes mellitus, hemoroid, tuberculosis, glomerulonefritis, pneumonia, dan hepatitis.alami oedem.

Variabel penelitian dalam penelitian ini adalah :

- Variabel terikat : Kejadian anemia pada ibu hamil.

- Variabel bebas: usia ibu hamil, paritas, jarak kelahiran, usia kehamilan, dan pengetahuan.

HASIL

Analisis Univariat

Tabel 1 Tabel Distribusi Frekuensi Responden Berdasarkan Usia Ibu Hamil

\begin{tabular}{lcc}
\hline Usia Ibu Hamil & Frekuensi & Presentase \\
\hline$<20$ tahun & 19 & $38,8 \%$ \\
$20-35$ tahun & 21 & $42,9 \%$ \\
$>35$ tahun & 9 & $18,4 \%$ \\
\hline Jumlah & 49 & $100 \%$ \\
\hline
\end{tabular}

Dari tabel Distribusi Frekuensi Responden Berdasarkan Usia Ibu Hamil diatas terlihat usia ibu hamil terbanyak yaitu usia $<20$ tahun dan $>35$ tahun sebanyak 28 responden $(75,1 \%)$, selanjutnya usia $<20$ tahun sebanyak 19 responden $(38,8 \%)$, usia > 35 tahun sebanyak 9 responden $(18,4 \%)$.

Dari tabel Distribusi Frekuensi Responden Berdasarkan Paritas diatas terlihat paritas $<4$ sebanyak 45 responden $(81,63 \%)$, dan paritas $\geqq 4$ sebanyak 4 responden $(8,17 \%)$.
Tabel 2 Tabel Distribusi Frekuensi Responden Berdasarkan Paritas

\begin{tabular}{lcc}
\hline \multicolumn{1}{c}{ Paritas } & Frekuensi & Presentase \\
\hline$\geqq 4$ & 4 & $8,17 \%$ \\
$<4$ & 45 & $91,83 \%$ \\
\hline Jumlah & 49 & $100 \%$ \\
\hline
\end{tabular}

Tabel 3 Tabel Distribusi Frekuensi Responden Berdasarkan Jarak Kelahiran

\begin{tabular}{lcc}
\hline Jarak Kelahiran & Frekuensi & Presentase \\
\hline$<2$ tahun & 26 & $53,1 \%$ \\
$\geq 2$ tahun & 23 & $46,9 \%$ \\
\hline Jumlah & 49 & $100 \%$ \\
\hline
\end{tabular}

Dari tabel Distribusi Frekuensi Responden Berdasarkan Jarak Kelahiran diatas terlihat jarak kelahiran <2 tahun sebanyak 26 responden $(53,1 \%)$, dan jarak kelahiran $\geq 2$ tahun sebanyak 23 responden $(46,9 \%)$.

\section{Tabel 4 Tabel Distribusi Frekuensi Responden} Berdasarkan Usia Kehamilan

\begin{tabular}{lcc}
\hline Usia Kehamilan & Frekuensi & Presentase \\
\hline TM I & 9 & $18,4 \%$ \\
TM II & 15 & $30,6 \%$ \\
TM III & 25 & $51 \%$ \\
\hline Jumlah & 49 & 100 \\
\hline
\end{tabular}

Dari tabel Distribusi Frekuensi Responden Berdasarkan Usia Kehamilan diatas terlihat TM III sebanyak 25 responden $(51,0 \%)$, TM II sebanyak 15 responden (30,6\%), TM I sebanyak 9 responden $(18,4 \%)$.

Dari tabel Distribusi Frekuensi Responden Berdasarkan Pengetahuan dibawah terlihat pengetahuan kurang sebanyak 28 responden $(57,1 \%)$, dan pengetahuan baik sebanyak 21 responden $(42,9 \%)$.

Tabel 5 Tabel Distribusi Frekuensi Responden Berdasarkan Pengetahuan

\begin{tabular}{lcc}
\hline Jarak Kehamilan & Frekuensi & Presentase \\
\hline Baik & 21 & $42,9 \%$ \\
Kurang & 28 & $57,1 \%$ \\
\hline Total & 49 & $100 \%$ \\
\hline
\end{tabular}


Tabel 6 Tabel Distribusi Frekuensi Responden Berdasarkan Kejadian Anemia

\begin{tabular}{lcc}
\hline Kejadian Anemia & Frekuensi & Presentase \\
\hline Anemia & 26 & $53,1 \%$ \\
Tidak Anemia & 23 & $46,9 \%$ \\
\hline Total & 49 & $100 \%$ \\
\hline
\end{tabular}

Dari tabel Distribusi Frekuensi Responden Berdasarkan Kejadian Anemia diatas terlihat kejadian anemia sebanyak 26 responden $(53,1 \%)$, dan tidak anemia sebanyak 23 responden (46,9\%).

\section{Analisis Bivariat}

Analisa ini digunakan untuk melihat hubungan antara variabel yang diteliti dengan kejadian KEK pada ibu hamil, hubungan antara usia ibu hamil, paritas, jarak kelahiran, usia kehamilan, dan pengetahuan. Uji statistik yang dilakukan pada analisis bivariat ini adalah chi square dengan derajat kepercayaan 95\% $(\alpha=95 \%)$. Berdasarkan hasil uji statistik akan diperoleh nilai probabilitas ( $p$ value) $<0,05$ (pada $\mathrm{Cl} ; 95 \%$ ) maka $\mathrm{HO}$ ditolak dan $\mathrm{Ha}$ diterima yang bearti ada hubungan yang bermakna dan jika probabilitas ( $p$-value) $\geq 0,05$ maka $\mathrm{HO}$ diterima dan $\mathrm{Ha}$ ditolak yang bearti tidak ada hubungan yang bermakna (Siswanto, Susila dan Suyanto, 2013).

Tabel 7 Hubungan Usia Ibu Hamil dengan Kejadian Anemia

\begin{tabular}{|c|c|c|c|c|c|c|c|}
\hline \multirow{2}{*}{\multicolumn{2}{|c|}{ Variabel }} & \multicolumn{2}{|c|}{ Kejadian Anemia } & \multirow{2}{*}{$\mathrm{n}$} & \multirow{2}{*}{$p$} & \multirow{2}{*}{ OR } & \multirow{2}{*}{$\mathrm{Cl}$} \\
\hline & & Anemia & Tidak Anemia & & & & \\
\hline Usia lbu & $<20$ tahun dan $>35$ tahun & 22 & 6 & 28 & 0000 & 15583 & $3787-6412$ \\
\hline Hamil & 20-35 tahun & 4 & 17 & 21 & 0,000 & (10, & $0,101-04,12$ \\
\hline
\end{tabular}

Tabel diatas menunjukkan bahwa sebagian besar responden adalah usia $<20$ tahun dan $>35$ tahun, dengan hubungan yang signifikan antara usia ibu hamil dengan kejadian anemia $(p 0,000)$ dengan resiko usia ibu hamil<20 tahun dan $>35$ tahun dapat menyebabkan kejadian anemia sebesar 15 kali lipat.

Tabel 8 Hubungan Paritas dengan Kejadian Anemia

\begin{tabular}{|c|c|c|c|c|c|c|c|}
\hline \multirow{2}{*}{\multicolumn{2}{|c|}{ Variabel }} & \multicolumn{2}{|c|}{ Kejadian Anemia } & \multirow{2}{*}{$\mathrm{N}$} & \multirow{2}{*}{$P$} & \multirow{2}{*}{ OR } & \multirow{2}{*}{$\mathrm{Cl}$} \\
\hline & & Anemia & Tidak Anemia & & & & \\
\hline \multirow{2}{*}{ Paritas } & $\geqq 4$ & 3 & 1 & 4 & \multirow{2}{*}{0,472} & \multirow{2}{*}{ - } & \\
\hline & $<4$ & 23 & 22 & 45 & & & - \\
\hline
\end{tabular}

Tabel diatas menunjukkan bahwa sebagian besar responden dengan paritas $<4$, dengan hubungan yang tidak signifikan antara paritas dengan kejadian anemia ( $p 0,472)$.

Tabel 9 Hubungan Jarak Kelahiran dengan Kejadian Anemia

\begin{tabular}{|c|c|c|c|c|c|c|c|}
\hline \multirow{2}{*}{\multicolumn{2}{|c|}{ Variabel }} & \multicolumn{2}{|c|}{ Kejadian Anemia } & \multirow{2}{*}{$\mathrm{n}$} & \multirow{2}{*}{$p$} & \multirow{2}{*}{ OR } & \multirow{2}{*}{$\mathrm{Cl}$} \\
\hline & & Anemia & Tidak Anemia & & & & \\
\hline \multirow[t]{2}{*}{ Jarak kelahiran } & $<2$ tahun & 20 & 3 & 23 & \multirow[t]{2}{*}{0,000} & \multirow[t]{2}{*}{22,222} & \multirow{2}{*}{$4,869-101,420$} \\
\hline & $\geq 2$ tahun & 6 & 20 & 26 & & & \\
\hline
\end{tabular}

Tabel diatas menunjukkan bahwa sebagian besar responden dengan jarak kelahiran $\geq 2$ tahun, dengan hubungan yang signifikan antara jarak kelahiran dengan kejadian anemia ( $p 0,000)$ dengan resiko jarak kelahiran $<2$ tahun dapat menyebabkan kejadian anemia sebesar 22 kali lipat.
Tabel dibawah menunjukkan bahwa sebagian besar responden dengan usia kehamilan TM III, dengan hubungan yang signifikan antara usia kehamilan dengan kejadian anemia (p 0,000) dengan resiko usia kehamilan TM I dan II dapat menyebabkan kejadian anemia sebesar 19 kali lipat. 
Tabel 10 Hubungan Usia Kehamilan dengan Kejadian Anemia

\begin{tabular}{|c|c|c|c|c|c|c|c|}
\hline \multirow{2}{*}{\multicolumn{2}{|c|}{ Variabel }} & \multicolumn{2}{|c|}{ Kejadian Anemia } & \multirow[b]{2}{*}{$\mathrm{n}$} & \multirow[b]{2}{*}{$\mathrm{p}$} & \multirow[b]{2}{*}{ OR } & \multirow[b]{2}{*}{$\mathrm{Cl}$} \\
\hline & & Anemia & $\begin{array}{c}\text { Tidak } \\
\text { Anemia }\end{array}$ & & & & \\
\hline Usia kehamilan & $\begin{array}{c}\text { TM III } \\
\text { TM I dan II }\end{array}$ & $\begin{array}{c}21 \\
5\end{array}$ & $\begin{array}{c}4 \\
19\end{array}$ & $\begin{array}{l}25 \\
24\end{array}$ & 0,000 & 19,950 & $4,662-85,380$ \\
\hline
\end{tabular}

Tabel 11 Hubungan Pengetahuan dengan Kejadian Anemia

\begin{tabular}{|c|c|c|c|c|c|c|c|}
\hline \multirow{2}{*}{\multicolumn{2}{|c|}{ Variabel }} & \multicolumn{2}{|c|}{ Kejadian Anemia } & \multirow[b]{2}{*}{$n$} & \multirow[b]{2}{*}{$p$} & \multirow[b]{2}{*}{ OR } & \multirow[b]{2}{*}{$\mathrm{Cl}$} \\
\hline & & Anemia & $\begin{array}{l}\text { Tidak } \\
\text { Anemia }\end{array}$ & & & & \\
\hline \multirow{2}{*}{ Pengetahuan } & Baik & 18 & 3 & 21 & \multirow{2}{*}{0,000} & \multirow{2}{*}{15,000} & \multirow{2}{*}{$3,443-65,355$} \\
\hline & Kurang & 8 & 15 & 23 & & & \\
\hline
\end{tabular}

Tabel diatas menunjukkan bahwa sebagian besar responden dengan pengetahuan kurang, dengan hubungan yang signifikan antara pengetahuan dengan kejadian anemia ( $p$ 0,000) dengan resiko pengetahuan kurang dapat menyebabkan kejadian anemia sebesar 15 kali lipat.

\section{PEMBAHASAN}

\section{Hubungan Usia Ibu Hamil dengan Kejadian} Anemia

Dari hasil penelitian didapatkan responden usia $<20$ tahun dan $>35$ tahun yang mengalami kejadian anemia sebnayak 22 orang $(44,9 \%)$. Hal ini sesuai dengan Depkes (2014) dimana kadar $\mathrm{Hb}$ 7,0-10,0 mg/dl banyak ditemukan pada kelompok umur $<20$ tahun sebanyak $46 \%$ dan kelompok umur 35 tahun atau lebih sebanyak $48 \%$. Bila umur ibu pada saat hamil relatif muda ( $<20$ tahun) akan beresiko terkena anemia, hal ini dikarenakan pada umur tersebut masih terjadi pertumbuhan yang membutuhkan zat gizi lebih banyak dibandingkan dengan umur diatasnya. Bila zat gizi tidak terpenuhi, akan terjadi kompensasi zat gizi antara ibu dengan bayinya (Wijianto, 2012).

Usia seorang wanita pada saat hamil sebaiknya tidak terlalu muda dan tidak terlalu tua, umur yang kurang dari 20 tahun dan lebih dari 35 tahun beresiko tinggi untuk melahirkan. Kesiapan seorang perempuan untuk hamil jugameliputi kesiapan fisik, emosi, psikologi, sosial dan ekonomi (Depkes, 2014). Remaja adalah individu yang berumur 10-19 tahun. Penyebab utama kematian pada perempuan berumur 15-19 tahun adalah komplikasi kehamilan, persalinan, dan komplikasi keguguran.

Kehamilan dini mungkin akan menyebabkan para remaja muda yang sudah menikah merupakan keharusan sosial (karena mereka diharapkan untuk membukttikan kesuburan mereka), tetapi remaja tetap menghadapi resiko-resiko kesehatan sehubungan dengan kehamilan dini dengan tidak memandang status perkawinan mereka. Kehamilan yang terjadi pada sebelum remaja berkembang secara penuh, juga dapat memberikan resiko bermakna pada bayi termasuk cedera pada saat persalinan, berat badan lahir rendah, dan kemungkinan bertahan hidup yang lebih rendah untuk bayi tersebut. Wanita hamil kurang dari 20 tahun dapat merugikan kesehatan ibu maupun pertumbuhan dan perkembangan janin karena belum matangnya alat reproduksi untuk hamil.

Penyulit pada kehamilan remaja ( $<20$ tahun) lebih tinggi dibandingkan kurun waktu reproduksi sehat antara 20-30 tahun, keadaan tersebut akan makin menyulitkan bila ditambah dengan tekanan (stres) psikologi, sosial, ekonomi, sehingga memudahkan terjadinya keguguran. Kehamilan remaja dibawah usia 20 tahun mempunyai resiko; sering mengalami anemia, gangguan tumbuh kembang janin, keguguran, preamturitas, atau $\mathrm{BBLR}$, gangguan persalinan, preeklampsi, dan perdarahan antepartum (Prawirohardjo, 2014).

Resiko mengalami anemia dan keguguran spontan tampak meningkat dengan bertambahnya usia terutama setelah usia 30 tahun, baik kromosom janin itu normal atau tidak, wanita dengan usia yang lebih tua lebih besar kemungkinan mengalami keguguran baik janinnya normal atau abnormal. Semakin lanjut usia wanita, semakin tipis cadangan telur yang ada, indung telur juga semakin kurang peka terhadap rangsangan gonadotropin. Makin lanjut usia wanita, maka resiko terjadinya abortus makin meningkat disebabkan karena menurunnya kualitas sel telur atau ovum dan meningkatnya resiko kejadian kelainan kromosom (Prawirohardjo, 2014). 
Berbeda dengan penelitian Herawati, C., dkk (2010) bahwa dari 81 responden, dari 30 responden umur ibu yang beresiko sebagian besar ibu menderita anemia $(70 \%)$, dan dari hasil uji hubungan diketahui $p$ value $(0,332)$ yang berarti tidak ada hubungan antara umur dengan kejadian anemia gizi pada ibu hamil. Juga penelitian yang dilakukan oleh Lulu (2009) yang menyatakan bahwa tidak ada perbedaan yang bermakna antara umur ibu yang berumur 20 tahun dan $>35$ tahun dengan ibu yang berumur antara 20-35 tahun ( $p>0.05$ ). Ibu yang berumur dibawah 20 tahun dan lebih dari 35 tahun lebih rentan menderita anemia disebabkan oleh faktor fisik dan psikis. Wanita yang hamil di usia kurang dari 20 tahun beresiko terhadap anemia karena pada usia ini sering terjadi kekurangan gizi. Hal ini muncul biasanya karena usia remaja menginginkan tubuh yang ideal sehingga mendorong untuk melakukan diet yang ketat tanpa memperhatikan keseimbangan gizi sehingga pada saat memasuki kehamilan dengan status gizi kurang. Sedangkan ibu yang berusia diatas 35 tahun rentan terhadap penurunan daya tahan tubuh, sehingga mengakibatkan ibu hamil mudah terkena infeksi dan terserang penyakit (Lulu, 2009).

\section{Hubungan Paritas dengan Kejadian Anemia pada Ibu Hamil}

Dari hasil penelitian didapatkan paritas $<4$ sebanyak 45 responden $(91,83 \%)$, hal ini sesuai dengan penelitian Nurhidayati (2013) dimana distribusi tertinggi adalah paritas rendah yaitu jumlah anak yang pernah dilahirkan ibu baik hidup maupun mati $<4$ kali kelahiran yaitu sebanyak 79 responden $(97,5 \%)$. Dimana makin tinggi paritas maka makin tinggi resiko kematian maternal, yang dapat diantisipasi dengan program Keluarga Berencana (Prawirohardjo, 2014).

Paritas $\geq 4$ dapat meningkatkan frekuensi komplikasi padā kehamilan dan persalinan, seperti meningkatnya resiko terjadinya kematian janin didalam kandungan dan perdarahan sebelum dan setelah melahirkan dimana hal tersebut dapat berakibat fatal, sebab wanita yang sudah sering melahirkan dapat berakibat kerusakan pada pembuluh darah dan vaskularisasi dinding uterus akibat persalinan yang lampau, sehingga aliran darah ke plasenta tidak memadai, yang akhirnya dapat menurunkan fungsinya dan mempengaruhi sirkulasi nutrisi ke janin. Memiliki riwayat banyak mengeluarkan darah dapat menyebabkan terjadinya anemia pada kehamilan berikutnya (Prawirohardjo, 2014).
Dari penelitian Noverstiti, E. (2012) diketahui bahwa responden yang mengalami anemia lebih banyak pada paritas tinggi yaitu sebanyak $64,3 \%$, bila dibandingkan pada paritas rendah sebanyak $40,4 \%$. Penelitian tersebut juga menunjukkan tidak adanya hubungan antara

paritas dengan kejadian anemia, yang kemungkinan disebabkan oleh faktor lain yang mempengaruhi pada ibu hamil dengan paritas tinggi seperti sikap, tindakan, jarak kehamilan sebelumnya. Selain itu, pada saat penelitian beberapa responden ditemukan memiliki paritas $<4$, termasuk ibu hamil yang sedang hamil anak pertama, sehingga tidak diperoleh perbedaan yang bermakna antara ibu hamil yang anemia dengan yang tidak anemia.

Dari penelitian Herawati, C., dkk (2010) diketahui bahwa pada ibu yang mempunyai paritas beresiko sama-sama mempunyai resiko mengalami anemia gizi $(50 \%)$, dan dari hasil uji hubungan didapatkan $p$ value $(1,00) \quad$ yang berarti tidak ada hubungan antara paritas dengan kejadian ane mia gizi pada ibu hamil. Penelitian ini berbeda dengan hasil penelitian yang dilakukan oleh Mamah (2006) dalam Herawati, C., dkk (2010), pada ibu hamil di Puskesmas Kecamatan Majalengka, menyatakan bahwa ibu dengan paritas $\geq 4$ mempunyai resiko lebih tinggi dibanding dengan ibu yang mengalami paritas $<4$ kali, dengan nilai $p=0.024$. Anemia pada kehamilan disebabkan oleh adanya hemodilusi atau pengenceran darah. Secara fisiologis ibu dengan paritas atau riwayat kelahiran yang terlalu sering akan mengalami peningkatan volume plasma darah yang lebih besar sehingga menyebabkan hemodilusi yang lebih besar pula. Ibu yang telah melahirkan lebih dari 4 kali berisiko mengalami komplikasi serius seperti perdarahan, hal ini dipengaruhi keadaan anemi selama kehamilan. Disamping itu pendarahan yang terjadi mengakibatkan ibu banyak kehilangan haemoglobin dan cadangan zat besi menurun sehingga kehamilan berikutnya menjadi lebih berisiko untuk mengalami anemia lagi (Herawati, C., dkk, 2010).

\section{Hubungan Jarak Kelahiran dengan Kejadian Anemia pada lbu Hamil}

Dari hasil penelitian didapatkan jarak kelahiran $<2$ tahun yaitu sebanyak 26 responden $(53,1 \%)$. Hal ini sesuai dengan penelitian Nurhidayati (2013) dimana distribusi tertinggi adalah jarak kelahiran $>2$ tahun sampai $<10$ tahun sebanyak 53 responden (66,3\%) (Nurhidayati, 2013). Jarak kelahiran terlalu dekat dapat 
menyebabkan terjadinya anemia. Salah satu faktor yang dapat mempercepat terjadinya anemia pada wanita hamil adalah jarak kelahiran pendek, karena kondisi ibu masih belum pulih dan pemenuhan kebutuhan zat-zat gizi belum optimal, tetapi ia sudah harus memenuhi kebutuhan nutrisi janin yang dikandungnya (Prawirohardjo, 2014).

Dari penelitian Noverstiti, E. (2012) diketahui bahwa responden yang mengalami anemia lebih banyak pada jarak kehamilan yang dekat yaitu sebanyak $75,0 \%$ bila dibandingkan pada jarak kehamilan yang jauh sebanyak 31,7 \%. Berdasarkan hasil uji menggunakan Continuity Corrections, didapatkan nilai $p=0,004(p<0,05)$ yang menunjukkan terdapat hubungan yang signifikan antara jarak kehamilan sebelumnya dengan kejadian anemia pada ibu hamil trimester III. di wilayah kerja Puskesmas Air Dingin kota Padang pada tahun 2012.

\section{Hubungan Usia Kehamilan dengan Kejadian Anemia pada Ibu Hamil}

Dari hasil penelitian didapatkan usia kehamilan terbanyak ada pada TM III yaitu sebanyak 25 responden $(51,0 \%)$ dengan p-value 0,000. Menurut Herawati, C., dkk (2010) meningkatnya usia kehamilan ibu beresiko besar menimbulkan anemia, apabila tidak diimbangi dengan pola makan yang seimbang dan konsumsi Fe secara teratur. Dimana pada ibu hamil di Puskesmas Bandar Jaya Lahat Kabupaten Lahat diduga faktor rendahnya kesadaran ibu hamil TM III untuk mengkonsumsi tablet besi sangat mempengaruhi.

Penelitian Herawati, C., dkk (2010) menyebutkan bahwa hubungan antara umur dengan kejadian anemia gizi pada ibu hamil (p 0,003). Status anemia pada kehamilan menunjukkan bahwa proporsi anemia pada kehamilan trisemester III sebesar $72.7 \%$ ini menunjukan bahwa umur kehamilan trisemester III lebih banyak menderita anemia dibanding trisemester I dan trimester II. Hemodilusi atau pengenceran darah selama kehamilan akan mencapai maksimal 5-8 bulan, faktor hemodilusi ini dapat menyebabkan kadar hemoglobin darah ibu menurun hingga mencapai $10 \mathrm{gr} / \mathrm{dl}$. Oleh sebab itu, semakin meningkatnya usia kehamilan ibu maka resiko untuk menderita anemia menjadi semakin besar apabila tidak diimbangi dengan pola makan yang seimbang dan konsumsi Fe secara teratur.

Hal ini berbeda dengan penelitian Martuti dan Sukati (2014) yang menyatakan bahwa ada kecenderungan hubungan negaif antara umur kehamilan dengan kadar $\mathrm{Hb}$ ibu hamil. Hal ini disebabkan oleh karena terjadinya perubahan fisiologis pada kehamilan yang dimulai pada minggu ke-6 kehamilan yaitu bertambahnya volume plasma yang mencapai puncaknya pada minggu ke-26, sehingga mengakibatkan penurunan kadar $\mathrm{Hb}$.

\section{Hubungan Pengetahuan dengan Kejadian Anemia pada lbu Hamil \\ Dari hasil penelitian didapatkan bahwa} pengetahuan terbanyak yaitu pengetahuan kurang sebanyak 28 responden $(57,1 \%)$, dimana hal ini sejalan dengan penelitian Salmariantity (2012) yang menyatakan bahwa prevalensi ibu hamil yang mengalami anemia dengan pengetahuan kurang sebanyak 48 responden $(66,7 \%)$ dan pengetahuan baik sebanyak 24 responden (33,3\%). Pengetahuan gizi dan kesehatan akan berpengaruh terhadap pola konsumsi pangan. Semakin banyak pengetahuan tentang gizi dan kesehatan, maka akan semakin beragam pula jenis makanan yang dikonsumsi, sehingga dapat dapat memenuhi kecukupan gizi, mempertahankan kesehatan individu dan menghindari anemia. Tablet besi dapat menimbulkan efek samping yang mengganggu, sehingga ibu hamil cenderung menolak konsumsi obat tersebut. Penolakan tersebut sebenarnya berpangkal dari ketidaktahuan mereka bahwa selama kehamilan mereka memrlukan tambahan zat besi. Untuk itu agar dapat dipahami makan ibu hamil dirasakan perlu diberi pendidikan yang tepat mengenai bahaya yang mengancam akibat anemia, dimana salah satu penyebab anemia adalah defisiensi zat besi (Arisman, 2012).

Dari penelitian Noverstiti, E. (2012) diketahui bahwa responden yang mengalami anemia lebih banyak pada tingkat pengetahuan kurang yaitu sebanyak $100 \%$, bila dibandingkan pada tingkat pengetahuan sedang sebanyak $75,0 \%$, dan tingkat pengetahuan tinggi sebanyak 45,9\%. Berdasarkan hasil uji menggunakan Pearson Chi-Square, didapatkan nilai $p=0,000 \quad(p<0,05)$ yang menunjukkan terdapat hubungan yang sangat signifikan antara tingkat pengetahuan dengan kejadian anemia pada ibu hamil trimester III. Hasil ini sejalan dengan teori Benyamin Bloom bahwa perilaku terdiri atas kognitif (pengetahuan), afektif (sikap), dan psikomotor (tindakan). Yang berarti bahwa perilaku sehat untuk tidak menderita anemia dipengaruhi oleh pengetahuan tentang pengertian, penyebab, akibat, penanggulangan anemia.

\section{SIMPULAN}

Karakteristik usia ibu hamil terbanyak yaitu usia $<20$ tahun dan $>35$ tahun sebanyak 28 
responden $(75,1 \%)$, paritas $<4$ sebanyak 45 responden $(81,63 \%)$, jarak kelahiran $<2$ tahun sebanyak 26 responden $(53,1 \%)$, TM III sebanyak 25 responden $(51,0 \%)$, pengetahuan kurang sebanyak 28 responden $(57,1 \%)$, kejadian anemia sebanyak 26 responden $(53,1 \%)$.Ada hubungan yang bermakna antara usia ibu hamil dengan kejadian anemia di Puskesmas Bandar Jaya Lahat Kabupaten Lahat ( $p$-value $=0,000)$. Tidak ada hubungan yang bermakna antara paritas dengan kejadian anemia di Puskesmas Bandar Jaya Lahat Kabupaten Lahat ( $p$-value $=0,472)$. Ada hubungan yang bermakna antara jarak kelahiran dengan kejadian anemia di Puskesmas Bandar Jaya Lahat Kabupaten Lahat $(p-v a l u e=0,000)$. Ada hubungan yang bermakna antara usia kehamilan dengan kejadian anemia di Puskesmas Bandar Jaya Lahat Kabupaten Lahat $(p$-value $=0,000)$. Ada hubungan yang bermakna antara pengetahuan ibu hamil dengan kejadian anemia di Puskesmas Bandar Jaya Lahat Kabupaten Lahat $(p$-value $=0,000)$.

\section{SARAN}

Berdasarkan hasil penelitian peneliti menyarankan hal-hal sebagai berikut : Instansi kesehatan agar dapat meningkatkan edukasi terkait pengetahuan tentang kehamilan untuk mencegah kejadian anemia, kontrol kehamilan yang teratur di puskesmas atau tenaga kesehatan, usia kehamilan yang aman yaitu usia 20 sampai 35 tahun dan kehamilan yang terencana dengan pengaturan jarak kelahiran $>2$ tahun.Pasangan yang ingin memiliki anak diharapkan untuk mengikuti edukasi tentang kehamilan yang diadakan oleh instansi kesehatan setempat, memperhatikan usia kehamilan yang aman yaitu usia 20 sampai 35 tahun, dan memperhatikan jarak kehamilan yang aman $>2$ tahun.lbu hamil diharapkan dapat melakukan kontrol kehamilan yang teratur di puskesmas atau tenaga kesehatan, dan menjaga kehamilan agar terhindar dari kejadian aneia pada ibu hamil.

\section{DAFTAR PUSTAKA}

Arisman. Gizi Dalam Daur Kehidupan: Buku Ajar IImu Gizi. Buku Kedokteran EGC. Jakarta, 2012. Hal 113-125.

BKKBN. Gerakan Keluarga Berencana dan Keluarga Sejahtera. 2014. Hal 57-63.

Chairlain dan Estu Lestari. Pedoman Teknik Dasar Untuk Laboratorium Kesehatan. EGC. Jakarta, 2011. Hal 34-38.

Depkes RI. Pedoman Operasional Keluarga Sadar Gizi di Desa Siaga. Jakarta. 2009. Hal 57.

Depkes RI. Profil Kesehatan Indonesia. 2010.
Depkes RI. Studi Tindak lanjut Ibu Hamil. 2014. Hal 57-67.

Dinas Kesehatan Propinsi Sumatera Selatan. Profil Kesehatan di Sumatera Selatan. 2010.

Esse Puji, dkk. Hubungan Pengetahuan lbu dan Pola Konsumsi dengan Kejadian Anemia Gizi pada Ibu Hamil di Puskesmas KassiKassi. Media Gizi Pangan, 2012.

Fatmah. Gizi dan Kesehatan Masyarakat. Jakarta. Raja Grafindo Persada. 2014. Hal 66-70.

Handoko dan Proverawati, A. Nutrisi Janin dan Ibu Hamil. Yogyakarta, Nuha Medika. 2010. Hal 125-132.

Hartanto, H. Keluarga Berencana dan Kontrasepsi. Jakarta, 2003.

Haryan, I. Program Diet Ibu Hamil. Cakrawala. Yogyakarta, 2014. Hal 87-92.

Herawati, C., Astuti, S. and Cirebon, S., 2010. Faktor-faktor yang Berhubungan dengan Anemia Gizi pada Ibu Hamil di Puskesmas Jalaksana Kuningan Tahun 2010. Jurnal Kesehatan Kartika, 1(1), pp.51-8.

Jannah, N. Asuhan Kebidanan, Kehamilan. Yogyakarta, Andi. 2012. Hal 145-146.

Kementrian Kesehatan RI. Pedoman Interpretasi Data Klinik. 2011. Hal 13-16.

Kementrian Kesehatan RI. Profil Kesehatan Indonesia 2013. Hal 26-70.

Khomsan, A. Pengetahuan, Sikap dan Perilaku tentang Anemia pada Peserta dan Bukan Peserta Program Suplementasi Tablet Besi pada Ibu Hamil. Media Gizi dan Keluarga, 2013. Hal 1-7.

Lulu, 2009. Faktor yang berhubungan dengan status anemia pada asuhan antenatal di Puskesmas Kecamatan Pasar minggu Jakarta selatan. 2009. Tesis.: FKM UI. Depok

Manuaba, dkk. IImu Kebidanan Penyakit Kandungan dan Keluarga Berencana Edisi 2. Jakarta, EGC. 2010. Hal 237-238.

Martuti S dan Sukati S. Profil Kesehatn Ibu Hamil di Propinsi Jawa Barat dan Nusa Tenggara Barat. Penelitian Gizi dan Makanan Puslitbang Gizi Bogor, 2014.

Noverstiti, E., 2012. Faktor-faktor yang Berhubungan dengan Kejadian Anemia pada Ibu HamilTrimester III di Wilayah Kerja Puskesmas Air Dingin Kota Padang tahun 2012. STIKES Peringsewu Lampung.

Notoatmodjo, S. Metode Penelitian Kesehatan. Rineka Cipta. Jakarta, 2012. Hal 37-182. 
Prawirohardjo, S. Buku Acuan Nasional Pelayanan Kesehatan Maternal dan Nasional. Ed 1. Pt Bina Pustaka. Jakarta, 2014. Hal 281-294.

Saifuddin, Abdul Bari. IImu Kebidanan. Ed 3. EGC. Jakarta. EGC, 2012. Hal 69-75.

Salmarantity. Faktor-faktor Yang Berhubungan dengan Anemia pada Ibu Hamil di Wilayah Kerja Puskesmas Gajah Mada Tembilahan Kabupaten Indragiri Hilir Tahun 2012. Universitas Indonesia, 2012

Siswanto, S., Susila, D., \& Suyanto, D. Metodologi Penelitian Kesehatan dan Kedokteran. Bursa Ilmu. Yogyakarta. 2013.

Sudoyo. A, W, dkk. Buku Ajar Penyakit Dalam. Edisi 4. Pusat Penerbitan Departemen IImu Penyakit Dalam. FKUI. Jakarta, 2013. Hal 1109-1112.
Sunarsih dan Vivian. Komplikasi pada Kehamilan : Asuhan Kehamilan Untuk Kebidanan. Salemba Medika. Jakarta, 2013. Hal 4549.

Sylvia P.A. Patofisiologi Konsep-Konsep Penyakit. Edisi 6. Penerbit Buku Kedokteran EGC. Jakarta, 2006. Hal 256-257.

Wardinar, dkk. Buku Anemia pada Ibu Hamil dan Konsep Penatalaksanaan. Trans Info Media. Jakarta, 2007. Hal 56.

Wijianto, Dampak Suplementasi Tablet Tambah Darah dan Faktor-faktor yang Berpengaruh terhadap Anemia Gizi Ibu Hamil di Kabupaten Banggai, Propinsi Sulawesi Tengah. Bogor, 2012. 